\title{
Executive Perks: Compensation and Corporate Performance in China
}

\author{
Pattarin Adithipyangkul \\ Assistant Professor \\ Department of Accountancy, City University of Hong Kong \\ 83 Tat Chee Avenue, Kowloon Tong, Kowloon \\ Hong Kong \\ Tel: 852-2788-7919, Fax: 852-2788-7944 \\ padithip@cityu.edu.hk \\ Ilan Alon \\ Professor and Jennifer J. Petters Chair of International Business \\ Rollins College \\ 1000 Holt Avenue - 2723, Winter Park, FL 32789 \\ USA \\ Tel: 407-646-1512 \\ ialon@rollins.edu \\ Tianyu Zhang \\ Assistant Professor \\ Department of Accountancy, City University of Hong Kong \\ 83 Tat Chee Avenue, Kowloon Tong, Kowloon \\ Hong Kong \\ Tel: 852-2788-8043, Fax: 852-2788-7944 \\ tyzhang@ cityu.edu.hk
}

May 2009 


\title{
Executive Perks: Compensation and Corporate Performance in China
}

\begin{abstract}
Many studies have examined CEO compensation in developed countries, where a long tradition of disclosure renders data readily available. In emerging economies, particularly in China, where market-based compensation is a relatively new phenomenon, there are few studies of CEO compensation. In addition, information on the use of non-cash compensation is almost absent. Building on the general literature on CEO compensation, and Chinese economic and management studies, this article singularly contributes to the extant literature by (1) examining the motivational determinants of CEO perk compensation, on the one hand, and (2) exploring the relative contribution of perks to performance. We anticipate that perks can serve two roles in China: (1) to provide incentives to deter managerial shirking, and (2) to facilitate work and improve production. We find that perks are positively associated with current and future returns on assets, supporting the view that some types of perks may improve firm profitability and/or that perks are paid as a bonus to reward performance. Our findings from stratified samples suggest that perks may incentivize managers, even after controlling for firm fundamentals, such as firm size, growth opportunity, and leverage.
\end{abstract}

Keywords: Executive Compensation, Perks, Non-cash Compensation, Perquisites, Firm Performance 


\section{Introduction}

CEO compensation in China is a new subject of inquiry. Prior to the start of China's reforms in 1978, the Chinese economy relied on vestiges of Maoism whose tenets of communism dictated similar pay for all ranks of members of society. Even then, however, high-ranking officials and powerful elites benefited from preferential treatment and sundry perquisites (McGregor, 2005). One of the key elements of economic liberalization has been the modernization of economic rules and the corporatization of state-owned enterprises (SOE). Listed companies on the Shanghai and Shenzhen stock exchanges are increasingly accountable to shareholders, in addition to the state, and incentives have been promulgated to induce managers to increase profits and the value of the business. The marketization of the Chinese economy necessitated some legal reform by the China Securities Regulatory Commission (CSRC), which is modeled after U.S. and Hong Kong corporate governance and CEO compensation schemes (Firth, Fung, \& Rui, 2006).

Despite rapid economic reform, socio-economic and political elements of the past remain. The state continues to own listed companies, and the state/local government owners may exercise operational and strategic control. Compensation systems are often affected by local customs, traditions, and institutions (both formal and informal). In some SOEs, executive performance evaluations and promotion decisions are based mainly on whether the managers satisfy and act in the interests of the Chinese Communist Party and the state (Firth et al., 2006). Although political advancement is sometimes the primary motivation, cash incentive pay for top management is also a motivation (Kato \& Long, 2005). Another type of publicly traded firm in China is the family-controlled firm. Previous studies (e.g., Kato \& Long, 2005) find that cash incentive pay is also used as a motivation tool in family-controlled firms. Although some evidence on the positive relationships between current cash compensation and performance exists (suggesting the use of cash incentives to motivate 
management in China and elsewhere), less is known about the relationships between performance and other forms of compensation, such as deferred cash compensation, fringe benefits, and perks. This paper explores the relationships between perks and performance in the Chinese context.

Non-cash compensation in China, including perquisites such as entertainment, dining, cars, travel, drinks and karaoke bars, free personal mobile phones, and so forth, has not been well studied. In the Western context, the compensation literature is inconclusive about the impact of such compensation. Some works, for instance Jensen and Meckling (1976), address the possible agency problems related to executive perquisites. Other studies point out benefits of perks compensation, including tax savings, cost savings, productivity, a reduction in disutility from work, and a reduction in employee turnover (Dale-Olsen, 2007; Long \& Scott, 1982; Oyer, 2004; Rajan \& Wulf, 2006; Rosen, 2000). This article provides additional evidence to the growing literature on the impact of non-cash compensation by testing the specific case of China.

Perks can be an important form of compensation in China for two reasons. First, the agency literature suggests that compensation should be linked to performance to deter shirking (Eisenhardt, 1989). In addition to cash, perks may also be paid as a bonus to reward performance. Because of social equity pressures, Chinese firms may be constrained in the way they can use cash to motivate performance. Perks, which are less observable to the public, can be used as a substitute for cash to motivate managers. Herein, we use the term "incentive" to denote the use of perk compensation to motivate management to supply a proper work effort. Second, perk compensation, such as meals, entertainment, and travel, helps companies build useful connections (guanxi) with governmental officials and business partners, as guanxi is often built and maintained through lavish meals, banquets, gift giving, joint entertainment, and trips (Ai, 2006; Yeung \& Tung, 1996). Guanxi has been 
acknowledged in the literature as an important factor in doing business in China (Ai, 2006; Alon, 2003; McGregor, 2005). Luo and Chen (1997), for example, find that guanxi improves sales performance. ${ }^{1}$ Since perk expenditures are paid not only as part of executive non-cash compensation but also to build and maintain connections, we anticipate that perks will help improve firm performance. In addition to guanxi-related perks, we also consider perks that help facilitate work in general. Some kinds of perks, such as entertainment expenditures, tend to be mostly guanxi-related, i.e., most of the expenditure is likely to be spent on building and maintaining guanxi. Other kinds of perks are not completely related to guanxi. For example, a firm may provide its executive with a free mobile phone, which can be used for both work and personal communication. Only part of this expenditure will be used for the building and maintenance of guanxi. Below, the term "productivity" or "productive" benefit is used to refer to both guanxi-related and non-guanxi-related benefits of perks.

Our research question is whether perk compensation is beneficial in China. In particular, do Chinese firms pay perks as bonuses to motivate managerial performance (an incentive role) and do perks help enhance production (a productive role) in China? Although existing empirical evidence from Western countries suggests that non-cash compensation may be paid to enhance production or to facilitate work, the incentive role of non-cash compensation has not yet been thoroughly examined. The difficulties in investigating the incentive role of perks stem from the fact that, regardless whether perks perform an incentive role or a productive role, a positive association between perks and performance will be observed. This article finds a positive association between perks and current performance in a pooled sample. To distinguish between the two roles of perks, we stratify our samples into four groups by two dimensions, firm performance and cash compensation paid. If perks are

\footnotetext{
$1 \quad$ Although most of the previous literature highlights the potential benefits of guanxi on firm performance and empirical evidence exists to support this argument, some researchers, such as Chen and Chen (2009), believe that guanxi may have negative effects. However, Chen and Chen (2009) do not provide any evidence to support this conjecture.
} 
paid as bonuses to motivate managers, we anticipate that a strong positive relationship between perks and firm performance in a group of firms with lower cash compensation but higher firm performance. This is because this group includes firms that use fewer cash incentives to motivate managers. Because less cash is paid, cash incentives alone may not be sufficient to motivate managers. The better performance of this group implies that it is likely that the firms also use perk incentives to complement the cash incentives to motivate managers. Hence this group should exhibit the strongest positive relationship between perks and firm performance. If perks are paid because of their productive benefits, the relationship between perks and firm performance should not vary much across different groups, after controlling for other firm characteristics. We find that perks are significantly and positively associated with performance only in the group with higher performance but lower cash compensation, suggesting that the dominant role of perks in the short run may be an incentive role, rather than a productive role.

In addition to the relationships between perks and current performance, this paper examines the relationships between perks and future performance. In the U.S. context, Hayes and Schaefer (2000) find that future performance can be explained by current CEO cash compensation. One possible explanation for this result is that cash compensation is paid to reward managerial effort in the current period, which then contributes to long-term profitability. In addition to cash, perks may also be used to reward work effort that is longterm oriented. Consistent with the findings in the United States, we find that future firm performance (for up to three years) is positively associated with both current cash and perk compensation.

A number of studies empirically examine CEO cash compensation in China and its relationship to firm performance (the few exceptions include Firth et al., 2006; Kato \& Long, 2005). Firth et al. (2006) suggest that an understanding of the optimal CEO compensation is 
critical to the success of the economic reform in China. The authors find that pay sensitivities to performance are small and that the type of ownership matters. To our knowledge, no study to date has examined the relative influence of perk compensation on firm performance in China. Empirical evidence from Western countries suggests that non-cash compensation is paid because of its productive benefits, tax-savings and cost-savings benefits. Our study contributes to the existing empirical literature on non-cash compensation by providing empirical evidence to suggest that, in addition to the other benefits previously documented, perks can provide incentives to motivate managers to work hard in the Chinese context. Also, we find that the design of the cash incentive may influence the extent to which perks are positively associated with firm performance. This implies that practitioners should simultaneously design cash and non-cash compensation in a comprehensive package, rather than using them alone.

Our paper also has theoretical implications. Although much of the previous literature on non-cash compensation focuses on the productive role of perks, our findings suggest that perks may serve both incentive and productive roles. Theoretical guidance is needed to determine which role will be dominant in which situation and why. Theoretical work that simultaneously considers both roles of non-cash compensation will contribute much to our knowledge of non-cash compensation and will provide the necessary guidance for future empirical research. In addition, although the agency theory literature often considers excessive or luxurious perks as agency costs, we provide evidence to suggest that this may not be true in the Asian context. The cultural heritage may be one of the most important factors in determining an optimal compensation design.

The remainder of the paper is organized as follows. The next section reviews the background on Chinese executive compensation, provides a theoretical overview of perk compensation, and develops our research hypotheses. Next, the paper describes the sample 
data and research methods used in this study, including our models and reports on the empirical findings. The paper ends with the discussion of the research findings, limitations, and conclusions.

\section{Background on Chinese Executive Compensation and Hypotheses}

\section{A Brief History of the Chinese Compensation System}

There are relatively few studies on compensation in China and they are all recent. The scarcity of the literature can be attributed partly to the historical context of compensation in planned economies, where regulation trumps market principles in setting wages. Before 1980, Chinese state-owned enterprises were controlled by centralized planning whereby managers were responsible for meeting output targets. All output was sold to the government (Mengistae \& Xu, 2004). Compensation, determined centrally, was not based on performance (Chow, 1992). The components of compensation included cash compensation, social wages, and non-material incentives (recognition and honors) (Chow, 1992). Cash wages were paid based on region, industry, and employee characteristics, such as seniority, tenure, education, gender, and job title (Bai \& Xu, 2005; Kato \& Long, 2005). Cash bonuses were divided equally among the members of the group, making them more similar to wage supplements than to real bonuses (Chow, 1992). Social wages included pension/retirement benefits, insurance for illnesses, injuries, accidents, disabilities, and unemployment, maternity benefits, medical benefits, and collective benefits (such as subsidized accommodations, transportation, child-care, and recreational activities) (Chow, 1992).

During the 1980s, sweeping changes in the regulatory environment ushered in a new era of more liberalized compensation schemes. The Chinese government implemented several reforms to modernize executive compensation practices, as described in Mengistae and $\mathrm{Xu}$ (2004). The first phase of the reform, between 1980 and 1984, introduced various 
profit retention schemes. The output target was replaced by an output quota, which was below full production capacity. The output in excess of the specified quota could be sold on the market and the firms could retain a portion of the profits.

The second phase of the reform, starting from the end of 1984, replaced the profit remittances with a profit tax rate of 55 percent. The after-tax profit could be used for investment, R\&D, and/or bonuses and benefits for employees. Directors were empowered, especially in the making of personnel decisions. During the next phase, Contractual Responsibility Systems (CRSs) were implemented, whereby centralized planning was replaced by contracts between the SOEs and their supervisory bodies. The contracts, stipulating minimum profitability, productivity standards, and investment levels, usually lasted for three to four years. By signing a contract, the directors became personally responsible and their personal wealth was often held as a performance bond. Because of this risk, the directors' compensation could be up to ten times that of average workers.

According to Firth et al. (2006), since the economic reform boards of directors now determine management compensation based on the recommendations of the controlling shareholders. Due to the socialist environment, however, there seems to be a cap on management compensation as a multiple of the average worker's pay. Previous studies find executive compensation to range from three times that of an unskilled worker to seven times that of an average worker. Stock options are rarely offered. There has been some concern about under-compensation because on average the managers' salaries are only a fraction of those in international joint ventures.

As for the history of non-cash compensation in China, we find that the literature in the Chinese context is almost non-existent. In 2004 interviews with Chinese executives, Kato and Long (2005) found that the most common perks were a company car and a housing allowance. Other perks (the value of which was usually much smaller than the two perks 
mentioned above) included travel expenses, business gifts, and business apparel expenses. Work-related perks such as entertainment expenditures are not included in their study. The housing allowance was about 5-6 percent of the annual cash salary. Kato and Long (2005) estimate the value of personal use of a company car to be about 12 percent of cash compensation. Overall, perks ranged from 15 percent to 32 percent of total compensation. As for non-cash compensation in Hong Kong-owned or foreign-owned firms in China, Chiu, Luk, and Tang (2002) found that the most common non-cash compensation provided for employees at all levels was subsidized meals, accommodations, holiday or entertainment facilities, annual leave, paid sick leave, paid maternity leave, paid wedding leave, paid compassionate leave, accident insurance, and health insurance. Other allowances (e.g., an overtime allowance, illness allowance, and transportation allowance) were also paid.

\section{Theoretical Overview: Perk Compensation in China}

In the classic agency literature originating in the developed countries, Jensen and Meckling (1976) consider the possibility that executive perquisites represent agency problems. A manager only owns a fraction of the firm. Therefore, expenditures for perk consumption are borne by all the shareholders, but the benefits are enjoyed primarily only by the managers. The managers thus tend to consume too much. It is implicitly assumed here that the managers' cash compensation is independent of their perk consumption, and it is costly to monitor perk consumption.

In opposition to Jensen and Meckling (1976), Fama (1980) argues that managers' wages can be adjusted, ex ante or ex post, to account for the managers' consumption of perks so that the perks can be part of an optimal contract rather than an agency cost. Fama's (1980) view is consistent with the earlier literature on labor and macro-economics, which discusses the various benefits of non-cash compensation: (1) economies of scale by providing non-cash 
compensation to a large number of employees, (2) tax benefits, (3) productivity, i.e., the beneficial effects of consumption of the good on production, or the reduction in the employee's disutility from work, and (4) a reduction in employee turnover (Dale-Olsen, 2007; Long \& Scott, 1982; Oyer, 2004; Rajan \& Wulf, 2006; Rosen, 2000). One example of a perquisite that may have a productive impact is a corporate jet. On the one hand, a corporate jet is considered a luxury perquisite for a CEO. On the other hand, traveling by corporate jet helps the CEO reach her destination fresh and ready for negotiations or other important tasks.

Marino and Zábojník (2006) and Adithipyangkul (2007) characterize an optimal compensation contract as one that includes both perk and cash compensation. A firm that pays productive non-cash compensation will pay less cash and will provide fewer cash incentives to motivate managers (Adithipyangkul, 2007). The higher the productivity of the non-cash compensation, the greater the amount of non-cash compensation (Adithipyangkul, 2007; Marino \& Zábojník, 2006). Productive perks improve expectations about firm performance.

In addition to being paid as part of a fixed payment, perks may also be paid as a bonus to reward performance and hence to motivate employees. In this case, because perks and cash are substitutes, if perks are increased, cash bonuses should be reduced accordingly, and one should observe a positive relationship between perks and firm performance.

Empirical research in Western countries provides inconclusive evidence as to whether executive perks represent agency costs or an optimal contract design. Yermack (2006), in analyzing data on American CEOs' personal use of company planes, finds a negative relationship between perks and stock performance, supporting the argument that perks represent agency costs. Rajan and Wulf (2006), however, support Fama's (1980) view that perks can be part of an optimal contract design. They find that in the U.S. context, perks may be paid because they facilitate and enhance the CEO's work. The authors argue that a 
company plane tends to be more productive when the company's headquarters are located in a smaller county, or in a remote location far from a large, convenient airport, and when a firm's operations are more geographically dispersed. The authors find that it is more likely that a corporate jet will be used in such situations. For employees at the lower levels, evidence is mixed regarding whether non-cash compensation or fringe benefits improve performance, e.g., whether flexible working hours improve worker productivity (Pierce \& Newstrom, 1980).

In the Chinese context, perks can be an important form of compensation because Chinese firms tend to be constrained in the way they can use cash to compensate managers. Due to social equity pressures, there seems to be a cap on management compensation as a multiple of the average worker's pay (Firth et al., 2006). Large cash compensations may attract criticism and create the perception of unfair income distribution and unwarranted managerial privilege. Chinese companies that need to find an alternative tool to motivate managers may resort to perk compensations. Perk compensation is less observable to the public, and some perks that are work-related may attract less criticism. Therefore, perks can be paid as part of the bonus to motivate management. If perks are paid as a bonus to motivate managers, a positive association between perks and firm performance should be observed.

Hypothesis 1: Perk compensation is positively associated with current firm performance in China.

Although a positive association between perks and firm performance can be attributed to the use of perks to motivate managers, in China perks may serve another purpose as well. The Chinese work environment is encumbered by both market and non-market elements with unique institutional features. One such feature affecting perk consumption is the use of guanxi to build business relations. Guanxi, loosely defined as "connections," with governmental officials and business partners is crucial for long-term business success, and 
guanxi is often built through lavish meals, trips, and gift giving (Ai, 2006; Luo \& Chen, 1997; Yeung \& Tung, 1996). But guanxi can also lead to nepotism, cronyism, favoritism, and some forms of corruption, as defined by Western standards (Alon, 2003).

Expenditures on entertainment, meals, travel, and communications hence serve two purposes in the case of Chinese firms. On the one hand, such perks are consumed by managers and hence are considered part of the managers' total compensation, representing the costs to the firm. On the other hand, these expenditures help to build and maintain guanxi, which can lead to higher profitability. In addition to guanxi-related benefits, some types of perks, such as mobile phones, can help facilitate work in general. Therefore, perks can have productive value in China by improving firm performance. No matter whether perks play a productive or an incentive role, they will be positively associated with current firm performance.

To differentiate the productive role of perks from the incentive role of perks, we use a sample stratification technique. Fama (1980) implies that perk incentives and cash incentives are substitutes in the sense that more perk incentives will be introduced if cash compensation cannot sufficiently motivate executives. The incentive efficiency of cash compensation is investigated through its association with contemporaneous performance. Cash compensation is considered under- (over-) paid if it is low (high) when firm performance is good (bad). In both of these situations, it seems that cash compensation does not play a sufficient incentive role. Additional incentive mechanisms, such as perks, may be needed when the executive is under-paid in cash. Such additional incentives through perks are unnecessary, or even redundant, however, when cash compensation is adequately paid or over-paid. Thus, if the perks are paid to motivate management, we should observe the strongest positive relationship between perks and performance in firms that under-pay their executives in terms of cash compensation. 
To execute the above test, we create four sub-samples stratified by two dimensions, cash compensation and performance, resulting in four separate groups, as shown in Figure 1 below.

\section{Insert Figure 1 here.}

First, consider the case where perks are paid mainly as a substitute for a cash bonus to motivate the manager. Group (1), firms with lower cash pay but higher performance, is likely to represent the group of firms that use fewer cash incentives to motivate managers. Because there are fewer cash incentives, the cash incentives alone may be insufficient to motivate managers. The better performance of this group suggests that perk incentives are used to complement cash incentives. Hence we anticipate a positive relationship between perks and firm performance for group (1). Group (2), firms with higher cash pay and lower performance, represents firms with agency problems. The consumption of perks is more likely to be a form of the appropriation of private benefits by management. We anticipate a negative relationship between firm performance and perks for this group. For groups (3) and (4), cash compensation seems to be aligned with performance so that less (more) cash is paid when performance is low (high), implying that firms in these groups may not need perk incentives to complement cash incentives to motivate managers. Cash incentives alone may be sufficient. Thus, the association between perks and performance for groups (3) and (4) should be weaker than that for group (1). No relationship will be observed if cash compensation alone can sufficiently deter managerial shirking. Our prediction is summarized in Hypothesis 2 below.

Hypothesis 2: A positive relationship between perks and performance is strongest among firms with lower cash compensation but higher performance.

In contrast, if the main role of perks is to improve productivity rather than to motivate managers, then after controlling for the firm characteristics, there may not be much of a difference in terms of the size of the positive association between the perks and the current 
performance for groups (1), (3), and (4). The relationship between perks and cash compensation for group (2) may be more subtle because group (2) includes firms with agency problems. Some of the perks consumed may actually help improve firm performance, whereas others may simply be agency costs that worsen firm profitability. The net effect ranges from a smaller positive association to a negative association between perks and performance.

In addition to the relationships between current cash compensation and current performance, researchers find positive relationships between current cash compensation and future performance (Hayes \& Schaefer, 2000). This result can be explained as follows. To prevent managerial myopia, any managerial effort in the current period which will lead to long-term profitability should be rewarded. A bonus for the current period will thus reward short-term-oriented effort and long-term-oriented effort. The latter will result in a positive association between current compensation and future performance. In addition to cash, perks can also be paid as a bonus to reward long-term-oriented effort. Therefore, current perk compensation is expected to be positively associated with future performance. Furthermore, perks, especially guanxi-related perks, may benefit a company in the long run. Chinese business culture is long-term oriented and guanxi may help ensure business success and create long-term competitive advantages (Ai, 2006). Conceptualized in this way, guanxi can contribute to a firm's value creation. This is because reciprocal guanxi relationships are longterm oriented; a favor done in the current period may be returned in a future period (Park \& Luo, 2001). Therefore, the expenditures paid to build and maintain guanxi in the current period may benefit the firm in future periods. Based on these arguments, we test the following hypothesis.

Hypothesis 3: Perk compensation is positively associated with future firm performance in China. 
As for the control variables, the firm ownership structure in China affects compensation practices. Note that in Communist societies social equity is an important issue. Large executive compensation may attract criticism. As a result, SOEs are predicted to pay less cash compensation. This hypothesis is supported by previous studies on compensation, e.g., Firth, Fung, and Rui (2007). Although SOEs are found to pay less cash compensation, the relationship between perks and state ownership may be more subtle. On the one hand, because of the social equity issues, SOEs may pay less in terms of cash but more in terms of perks, because the latter are less observable to the public. On the other hand, in the Chinese context, perks such as entertainment and meals are also used to build and maintain guanxi. Non-SOEs are endowed with fewer political and governmental connections. Thus, it is reasonable to expect that non-SOEs will need to spend more on guanxi-related expenditures than SOEs. Therefore, whether or not more perks are paid in SOEs is inconclusive. In addition to the ownership structure, we control for other firm characteristics that are found to be determinants of cash compensation in China. These variables include firm size, growth opportunity, and leverage.

\section{A Benchmark: Cash Compensation in China}

In addition to the analysis based on perks, we investigate the relationship between cash compensation and firm performance as a benchmark for comparison. Agency theory suggests firms will link pay to performance to motivate managers (Eisenhardt, 1989). The performance measures should be informative about all aspects of CEO actions that contribute to the firm's short-term and long-term successes (Christensen \& Feltham, 2005). Current or lagged accounting numbers and stock returns are often used as measures of performance. Consistent with the suggestion to use incentive pay to solve agency problems, the cash compensation level in China is found to increase returns on sales (profit/sales) (Mengistae \& 
$\mathrm{Xu}, 2004)$, (lagged) returns on asset (Conyon \& He, 2008; Firth et al., 2007; Li, Moshirian, Nguyen, \& Tan, 2007), and (lagged) stock returns (Conyon \& He, 2008).

It should be noted here that the relationship between pay and performance may be more complicated in China than it is in developed economies. There are two types of Chinese firms: SOEs and family-controlled enterprises. In family-controlled firms, managers are often members of the owning families so that ownership and control are not separate and incentives are less important to deter managerial shirking. In SOEs, the state has an alternative tool to motivate managers, i.e., political advancement, so it may not need to strongly link pay to performance. In short, Chinese firms may not need to use incentive pay to solve the agency problems between principal and agent. However, in addition to the moral hazard problems whereby the principal's and the agent's interests are not aligned, another type of agency problems, called principal-principal agency problems, also exists in China. Principalprincipal agency problems arise when interests of the majority shareholders (of either the state or the controlling family) are not aligned with those of the minority shareholders (Young, Peng, Ahlstrom, Bruton, \& Jiang, 2008). For instance, the state may not allow employee layoffs, even when layoffs will be beneficial, because it wants to control unemployment rates.

Since the compensation reform in China, executive pay has been linked to performance. Researchers (e.g., Firth et al., 2007) generally argue that pay for performance will solve the moral hazard problems between the principal (owner) and the agent (manager). However, pay for performance may also help solve principal-principal agency problems (Young, Peng, Ahlstrom, Bruton, \& Jiang, 2008). In SOEs, where the state may be more concerned about goals other than profit maximization and where political advancement is used to motivate managers to achieve these goals, linking pay to performance helps to motivate managers to be concerned about firm performance and hence to be concerned about 
minority shareholders. In family-controlled firms, linking the manager's/owner's pay to performance makes asset misappropriations more costly to the manager because by "stealing" from the company, the manager receives less compensation. Based on the agency theory predictions above, we anticipate that cash compensation is positively associated with a firm's current performance.

It should be noted that accounting numbers, which measure firm performance in most previous studies, are based on history and may be short-term oriented. They may not capture CEO actions that contribute to business success in the long run. However, unobservable performance information may be reflected in the firm's future performance (Hayes \& Schaefer, 2000). Thus researchers may be able to use future firm performance as a proxy for the unobservable performance measure that is long-term oriented. Using U.S. data, Hayes and Schaefer (2000) find that future performance can be explained by current CEO compensation.

Chinese business culture is long-term oriented (Park \& Luo, 2001). To mitigate counter-productive myopic behavior, managerial efforts for the long-term prospects of the company should be rewarded. Thus, similar to that in the U.S. setting, we anticipate that current cash compensation is positively associated with future performance in Chinese companies.

The Chinese government has tried to modernize compensation practices since the 1980s. However, due to the Communist legacy and the social equity pressures, SOEs are expected to pay less cash compensation, possibly to avoid criticism from the public (Conyon \& He, 2008; Firth et al., 2006; Firth et al., 2007; Li et al., 2007). In non-SOEs, which are mostly family businesses, there should be less pressure regarding the amount of executive compensation. Therefore, we anticipate that the level of cash compensation is lower in SOEs than in non-SOEs. 
The control variables included in our analysis include firm size, growth opportunity, and leverage, as suggested by the previous literature. Mengistae and Xu (2004), Firth et al. (2006), Firth et al. (2007), Li et al. (2007), and Conyon and He (2008) find that the compensation level increases with firm size, possibly because larger firms are more complex and hence require more management skills or because they have a larger resource base to attract top talent. Growth opportunity is also found to be positively associated with executive compensation (Conyon \& He, 2008), possibly because a high-growth firm requires a more competent manager who deserves higher pay. In addition to shareholder monitoring, Firth et al. (2007) find that CEO compensation decreases in the degree of leverage, implying that monitoring by debt holders reduces CEO compensation. Additionally, we control for the year of operation and the industry effects.

\section{Sample and Methodology}

\section{Sample and Data Sources}

In the footnotes to their cash flow statements, Chinese listed companies are required to disclose cash expenditures for a list of operating items, such as meals and travel, transportation, communications, entertainment, $\mathrm{R} \& \mathrm{D}$, advertising, and so forth. We manually collected all the items disclosed in these notes for all public companies traded on the Chinese stock markets from 1999 to 2004. Some of these expenditures are partially consumed by managers. Company cars and mobile phones, for example, are used for both work and personal transportation and communications. We anticipate that expenditures for meals, travel, company cars, communications, socializing, and entertainment involve personal consumption by management. The sum of these expenditures is denoted by PERKS1, which is a proxy for management perquisites. Because we could not determine the extent to which the expenditures are spent for the management's personal consumption, the variable PERK1 
may not be a good proxy for management perquisites. Therefore, we also focused on the types of perks that seem to involve more of the managers' personal consumption, i.e., expenditures for meals, travel, and entertainment. The sum of these expenditures is denoted as PERKS2.

As a benchmark to compare with perk compensation, we also compiled the cash compensation for the top three executives in the company. The cash compensation data were collected from a database for China Stock Market and Accounting Research (CSMAR). The market and accounting data were also retrieved from CSMAR. The final sample includes 3,706 firm-year observations with available data for both perks and cash compensation. The distribution of the sample by fiscal year is reported in Panel A of Table 1. The number of firms by year increases from 161 in 2000 to 973 in 2004, indicating a growing number of firms listed on the Chinese stock markets as well as an improvement in disclosure quality. The distribution of the sample by industry is reported in Panel B of Table 1. More than 50 percent of our sample firms are in the manufacturing sector. This is consistent with the industry structure of the Chinese stock market.

\section{Insert Table 1 (Panel A \& B) About Here}

\section{Research Design}

We ran two regression models to investigate the relationships between current compensation and contemporaneous performance and between current compensation and future performance. First, we tested whether compensation was positively associated with current performance, with a particular emphasis on perk compensation. Second, we examined the relationship between firm current compensation and future performance. 
To test Hypothesis 1 (whether perks are positively associated with current performance), and Hypothesis 2 (whether the positive association between perks and performance is strongest in firms with less cash compensation and better performance), we followed the literature on executive compensation to run the following model for perks. We also ran the model for cash compensation as a benchmark for comparison.

$$
\begin{array}{r}
\text { PERK }_{i t}\left(\text { COMPENSATION }_{i t}\right)=\alpha+\beta_{1} \text { ROA }_{i t}+\beta_{2} \text { STATE }_{i t}+\beta_{3} L O G_{-} S A L E S_{i t} \\
+\beta_{4} L E V E R A G E_{i t}+\beta_{5} M B_{i t}+Y E A R+I N D U S T R Y+\varepsilon_{i t},
\end{array}
$$

where

$P_{E R K S}$ is the logarithm of perks for firm $i$ in year $t$.

COMPENSATION $_{i t}$ is the logarithm of cash compensation paid for the top three executives for firm $i$ in year $t$.

$R O A_{i t}$ is the return on assets for firm $i$ in year $t$.

$S T A T E_{i t}$ is the indicator for state-owned enterprises, which equals 1 if the firm is controlled by the state and 0 otherwise.

$L O G \_S A L E S_{i t}$, the proxy for size, is the logarithm of sales for firm $i$ in year $t$.

LEVERAGE $E_{i t}$ is the ratio of total liability to total assets for firm $i$ in year $t$.

$M B_{i t}$ is the market-to-book equity ratio for firm $i$ in year $t$.

YEAR stands for the yearly fixed effect.

INDUSTRY stands for the industrial effect.

In addition to the test variables, the control variables included in our analysis were firm size, leverage, growth opportunity, year of operation, and industry effects, as suggested by the previous literature. The standard error was clustered by firms with regard to repetition of the same firm in the analysis. This model was performed in the pooled sample to provide general evidence as to whether or not perks were generally positively associated with performance. 
We also ran the regression model for four sub-samples stratified by two dimensions, cash compensation and performance. The pooled sample was stratified into two sub-samples of firms with higher or lower cash compensation, with the median of the average cash compensation as the cutoff point. Then each sub-sample was stratified into two sub-samples of firms with higher or lower performance, with the median of the average ROA as the cutoff point. A firm with an average ROA above the median of the average ROA of each firm from 1999 to 2004 was regarded as having higher performance, whereas a firm with average compensation for the top three executives above the median of that for each firm from 1999 to 2004 was regarded as having higher pay. The stratification resulted in four sub-samples: (1) firms with lower cash compensation and higher performance, (2) firms with higher cash compensation and lower performance, (3) firms with lower cash compensation and lower performance, and (4) firms with higher cash compensation and higher performance.

\section{Current Compensation and Future Performance}

To investigate the relationships between current compensation and future performance, we ran the following model.

$$
\begin{aligned}
\text { ROA }_{i t+j}= & \alpha+\beta_{1} \text { COMPENSATION }_{i t}+\beta_{2} \text { PERKS }_{i t}+\beta_{3} \text { ROA }_{i t}+\beta_{4} \text { STATE }_{i t} \\
& +\beta_{5} \text { LOG_SALES }_{i t}+\beta_{6} \text { LEVERAGE }_{i t}+\beta_{7} M_{i t}+\text { YEAR }+ \text { INDUSTRY }+\varepsilon_{i t},
\end{aligned}
$$

where

$R O A_{i t+j}$ is the returns on assets for firm $i$ in year $t+j$ and $\mathrm{j}$ equals 1,2 , and 3 alternatively.

All the remaining variables are defined in the same way as those in model (1).

As suggested by Hayes and Schaefer (2000), if some unobservable aspects of performance are reflected in future performance and the managers are rewarded based on the unobservable performance measures, current cash compensation is expected to be positively associated with future firm performance. In other words, $\beta_{l}$ is expected to be positive. In 
addition, because perks (especially guanxi-related perks) may help improve performance in the long run or may be paid to reward management long-term oriented effort, $\beta_{2}$ is expected to be positive (Hypothesis 3). As in model (1), the standard errors were clustered by firm in the estimation.

\section{Results}

\section{Descriptive statistics}

Panel A of Table 2 provides the descriptive statistics of perks and cash compensation. PERKS1, which includes expenditures for meals, travel, company car, socializing, communications, and entertainment, has a mean and a median of 4.73 and 1.39 , respectively. PERKS2, which includes only meals, travel, and entertainment expenditures, has a mean and a median of 4.00 and 1.06 , respectively, each of which is only marginally lower than that of PERKS1. This means that meals, travel, and entertainment expenditures, which help managers build and maintain guanxi, are the main components of perks in Chinese firms. Compared with perks, cash compensation has a mean and a median of 0.42 and 0.30 respectively, which are both much lower than the perks consumed in the company. This difference can be attributed to the fact that perks are consumed by the entire management team whereas compensation is confined to the top three executives in the company.

Panel B of Table 2 reports the descriptive statistics of the firm's performance, measured as returns on assets (ROA) and other control variables, i.e., leverage, size, and market-to-book equity ratio. The variable STATE, which is an indicator for state-controlled firms, shows that about 79 percent of the firms in our sample are controlled by the state. We control for this ownership effect in all the models because we anticipate that the compensation structure, including perks and compensation, may vary between state- and nonstate-controlled firms. 


\section{Insert Table 2 (Panels A \& B) About Here}

\section{Current Compensation and Current Performance}

We anticipate that perks and current performance in China will be positively associated since perks are paid as a bonus to motivate management (Hypothesis 1). Table 3 reports the baseline model of the association between perks (cash compensation) and contemporaneous firm performance. The coefficients of the ROA in models (1) and (2) with PERKS1 and PERKS2 as the dependent variables are both 0.07, significant at the 5 percent level, supporting Hypothesis 1. We also anticipate the use of cash compensation for performance to mitigate agency problems so that cash compensation should increase as firm performance increases. The coefficient of the ROA is 0.019 , with a significance level at 1 percent, for cash compensation. This suggests that cash compensation is linked to performance in China.

\section{Insert Table 3 About Here}

In addition to performance, the level of compensation may be determined by the firm ownership structure. Non-SOEs are endowed with fewer political connections and hence may need to incur more expenditures to build guanxi. As a result, perks are expected to be higher in non-SOEs. We find that the STATE variable, an indicator for state-controlled firms, is not significantly associated with perks.

Cash compensation is regulated in state-controlled firms. Social equity pressures possibly limit the amount of cash compensation that SOEs can award managers. Cash compensation is thus expected to be lower in SOEs due to social equity concerns. The STATE variable is significantly negative in model (3), which means that formal cash compensation in state-controlled firms is lower than that in non-state-controlled firms. 
The coefficients for the remaining control variables are consistent with the findings in previous studies. Large and growing firms are more likely to pay higher cash compensation and perks to management, whereas highly leveraged firms will pay lower. The association between perks and firm fundamentals is the same as that between cash compensation and firm fundamentals. This provides evidence that perks and cash may be substitutes.

Table 4 reports the regression results for the four stratified sub-samples. The pooled sample is stratified by the level of cash compensation and by the ROA into four sub-samples: (1) firms with lower cash compensation but better performance, (2) firms with higher cash compensation but worse performance, (3) firms with lower cash compensation and worse performance, and (4) firms with higher cash compensation and better performance.

\section{Insert Table 4 about Here}

Group (1) includes firms with lower cash compensation but higher performance. This group is likely to represent firms that use fewer cash incentives to motivate performance. More perk compensation is expected to be paid as a substitute for cash bonuses to motivate performance, compared with firms in groups (3) and (4). Group (2) includes firms with higher cash compensation but lower performance. This group represents firms with agency problems so here we expect no or a negative relationship between perks and firm performance for this group. In short, we anticipate the strongest positive relationship between perks and firm performance for group (1) (Hypothesis 2).

The results for groups (1) and (2) are reported in Panel A of Table 4. Consistent with the stratification criteria, the association between cash compensation and performance becomes much weaker than that in the pooled sample analysis in Table 3. Cash compensation does not seem to have much of an incentive effect in these two sub-samples. However, the association between perks and performance becomes much stronger among firms with higher 
performance and lower pay in group (1). The coefficient of ROA with PERKS1 (PERKS2) as the dependent variable increases from $0.070(0.071)$ in Table 3 to $0.354(0.403)$ (see model [1] and model [2] in Panel A of Table 4 respectively). The relationships are statistically significant. The association between perks and performance becomes much weaker among firms with lower performance but higher pay in group (2). The coefficient of ROA with PERKS1 (PERKS2) as the dependent variable decreases from $0.070(0.071)$ in Table 3 to -0.08 (-0.068) (see model [4] and model [5] in Panel A of Table 4 respectively). The relationships between perks and performance for group (2) are negative, but insignificant.

The empirical evidence for the association between perks and compensation with performance for firms in groups (3) and (4) is provided in Panel B of Table 4 as a benchmark reference. These are firms with higher performance and higher pay or firms with lower performance and lower pay (cash pay and performance are linked). The association between cash compensation and firm performance becomes stronger for group (4). But we did not find any significant association between perks and firm performance. Overall, the results in Table 4 support Hypothesis 2. The main role of perks seems to be to reward current performance rather than to improve current performance.

\section{Current Compensation and Future Performance}

Because perks can be paid as a bonus to reward long-term-oriented work effort or perks may have long-term productive benefits, we anticipate a positive relationship between perks and future performance (Hypothesis 3). Our findings support this hypothesis, as shown in Table 5. The variable PERKS is positively associated with future performance. Future performance increases with current perks for up to three years. Additionally, current cash compensation may be positively associated with future performance because future performance may capture information about long-term-oriented managerial performance and 
cash bonuses are paid to reward long-term- oriented performance. The coefficient for COMPENSATION is positive and significant.

\section{Insert Table 5 about Here}

\section{Discussion}

As suggested by agency theory, much of the compensation literature considers the relationships between cash compensation and performance. Some of the previous studies in Western countries that examine the relationships between perks and performance find inconclusive evidence as to whether perks represent agency costs or an optimal compensation contract design. ${ }^{2}$ Whether non-cash compensation has productive value is also inconclusive. To the best of our knowledge, no previous study has investigated the relationships between perks and performance in the Chinese context.

Contrary to evidence from Western countries (e.g., Pfeffer and Sutton, 2006), our research suggests that perks are an important form of compensation in China. On average, top executives in Chinese companies spend about 4-5RMB million per year on perks, in contrast to average cash pay of about $0.42 \mathrm{RMB}$ million per year. Our results suggest that perks are paid as a substitute for cash to motivate managers and to improve performance in the long run.

Previous empirical studies, such as Rajan and Wulf (2006) and Oyer (2004), show that perks are more likely to be paid when they are expected to improve or facilitate production. Whether or not non-cash compensation actually leads to better performance is still inconclusive (Pierce \& Newstrom, 1980). Our paper contributes to the literature by providing additional evidence about the benefits of perks. We find that perks are positively associated with both current performance (in Table 3) and with future performance (in Table

2 See, for example, Yermack (2006) and Dale-Olsen (2007). 
5), suggesting that non-cash compensation may have productive benefits and may be used to motivate managers.

Our results that show that perks are positively associated with firm performance contradict findings by Yermack (2006), possibly because Yermack (2006) considers perks that are not related to work (e.g., personal use of a company aircraft), whereas we consider perks that help to build and maintain guanxi or perks that can help facilitate work. The positive association between perks and performance indicates that perks may not always simply represent agency costs whereby managers abuse the firm's resources through overconsumption. In contrast, our findings support Rosen (2000) and others who propose a possible beneficial impact of such compensation on production.

Although much of the previous empirical work in Western countries investigates the productive role of non-cash compensation, ${ }^{3}$ our findings based on stratified samples in Table 4 suggest that perks may also be paid to motivate managers in China. In Table 4, we find that perks are positively associated with performance only for group (1). In other words, firms that use fewer cash incentives are found to use perk incentives to augment the cash incentives, as implied by the positive association between perks and current performance. We find no significant association for those firms that use more cash incentives in groups (3) and (4). This implies that perks may be paid to motivate managers rather than to enhance production. Although we cannot exclude the possibility of short-term productivity from perks, this study contributes to the existing literature by suggesting that perks may be paid as a substitute for cash to reward managers.

The findings from the stratified sub-samples indicate that some firms may align perk incentives better than others, thus exhibiting a strong positive relationship between performance (ROA) and perk compensation. It should be noted that even for those firms that

See, for example, Dale-Olsen (2007), Oyer (2004), and Rajan \& Wulf (2006). 
seem to be afflicted by agency problems in group (2), the association between perks and performance is not significantly negative. If perks are purely a misappropriation of the shareholders' wealth, one may anticipate that excessive perks will lead to worse performance, so a significant negative association should be observed for group (2). The reason for an insignificant relationship may possibly be that some of the perk-related expenditures are spent productively, for example, to build guanxi, which helps improve firm performance. The extra expenditures that are misappropriated by management worsen performance. The two opposing forces possibly result in insignificant relationships between perks and performance.

Although we find that some companies use fewer cash incentives but more perk incentives than their peers to mitigate agency problems, our results imply that cash is still the main incentive tool for some companies. For firms with lower (higher) performance and lower (higher) cash compensation, perks are not significantly related to performance, implying that some firms may choose to motivate managers through cash incentives rather than through perk bonuses.

In addition to perks, our research investigates the comparative relationships between cash compensation and current and future performance. Similar to perks, cash compensation is found to be positively associated with current performance in the pooled sample. This result is consistent with previous Chinese studies, such as Mengistae \& Xu (2004), Conyon \& He (2008), Firth et al. (2007), and Li et al. (2007), which also report on the use of pay for performance in Chinese companies. Incentive pay may be used to deter the agency problems between the principal (shareholders) and the agent (managers) or to deter the agency problems between the principal (majority shareholders) and the principal (minority shareholders). Moreover, we anticipate that cash compensation should be positively associated with future performance, because some aspects of managerial effort which are long-term oriented and which are not observable to researchers may be captured by future 
performance. We find that cash compensation is positively related to future performance, consistent with the findings by Hayes and Schaefer (2000), which are based on U.S. data. This suggests that Chinese firms reward managerial effort related to both the short-term and long-term prospects of the company.

Furthermore, we anticipate that Chinese SOEs may use perks to compensate their managers competitively in the labor market. Since they may be limited in the amount they can give in the form of cash compensation (either because of regulations or institutional pressures), perks provide the firm with the ability to "hide" the total compensation package behind more opaque forms of compensation that are harder to track and criticize. Our research finds that state ownership has a negative and significant impact on cash compensation, as revealed in previous studies such as Firth et al. (2007). However, state ownership does not have a significant impact on perk compensation. This is possibly because on the one hand, a SOE faces more serious social equity pressures and therefore pays more in terms of perks because perks are more opaque to the public. On the other hand, non-SOEs may spend more on perks due to greater needs to build and maintain guanxi with politicians and government officials as well as suppliers and buyers.

Our findings relating to the relationships between cash compensation and the control variables are consistent with previous studies, such as Firth et al. (2007), Li et al. (2007), and Conyon and He (2008). We provide additional evidence on the relationships between perks and the variables that are the determinants of cash compensation in the previous literature. Table 3 shows that large companies with high sales volume are more likely to give both higher cash compensation and higher perk compensation; leverage has a negative and significant impact on both cash compensation and perk compensation, but the impact on perk compensation is more than five times larger. This suggests that companies in China whose ratio of total liability to total assets is larger are less likely to afford perks than they are able 
to afford cash compensation. The coefficient of market-to-book equity ratio (which measures future potential) is positive and significant for both cash compensation and perks, but the relative impact on perks is much larger (more than eight times larger for PERKS 1). Possibly this is because firms with more growth opportunities tend to invest more in perks to build guanxi.

In summary, our study contributes to the compensation literature by extending the agency literature that originated in the West to the Chinese context. Excessive or luxurious perks are often viewed as agency costs in the Western context. Our evidence suggests that excessive or luxurious perks such as lavish meals should not always be perceived of as management's theft of shareholders' wealth. Perk compensation is found to be positively associated with firm performance. The cultural context seems to be one of the most important factors in determining whether the Western theory is applicable to Asian settings. Previous empirical compensation literature focuses on the incentive role of cash compensation and the productive role of non-cash compensation. Our results suggest that perks can be paid both to motivate managers to supply greater efforts and to facilitate work. In other words, perks can perform both incentive and productive roles. Also, we find that the design of cash incentive compensation may influence the extent to which perks are positively related to firm performance. This leads to the practical implication that firms should carefully design both cash and non-cash compensation schemes simultaneously and comprehensively rather than designing each separately.

\section{Limitations and Future Research}

Asian countries are gaining economic prominence, but there are still many gaps in the existing literature and hence many unexplored research questions related to human resource management practice in Asia (Budhwar \& Debrah, 2009). More research is needed on non- 
cash compensation in Asian countries. We provide a first empirical at this important feature of compensation reform in China. But data are still lacking. For example, when data become available on stock options, comparisons with Western firms will be useful. Over time, however, the structure of compensation will change and replicated work may be required. In addition, we propose two reasons for why perks are positively associated with firm performance - (1) perks help facilitate work and build and maintain guanxi and guanxi in turn leads to business success, and (2) perks are paid as a bonus to mitigate agency problems. Because data on the breakdown of perks into fixed compensation components and bonus components are not publicly available, we cannot know to what extent perks are paid as part of fixed compensation to facilitate work or to build guanxi and to what extent perks are paid as bonuses to deter managerial shirking. Future case-study or survey research that gathers detailed data on the breakdown of perks into these two components will help us better understand the use of perk compensation in China.

In addition, although much of the previous literature focuses on the incentive role of cash compensation and the productive role of non-cash compensation, our results suggest that non-cash compensation can actually serve both roles. Future analytical research, considering both the incentive and productive roles simultaneously, is needed to provide guidance for non-cash compensation.

Furthermore, although the compensation literature often examines the use of incentive pay to solve the moral hazard problems between the principal and the agent, less of the earlier work considers the use of the compensation design to solve the principal-principal agency problems. A formal theory is needed to distinguish the use of incentive pay to solve principalagent agency problems from the use of incentive pay to solve principal-principal agency problems. 
Finally, there is a need to test the theories of compensation in relation to unique environments, in China or elsewhere, in order to develop general explanations across different systems. Although perks seem to be viewed rather negatively by investors in the West and the evidence is inconclusive as to the effects of perks on firms, the relationship between perks, especially guanxi-related perks, and firm performance may be different in East Asia where networking is a key to business success. Future studies should extend this framework to other countries, in both the developing and developed contexts.

\section{Acknowledgments}

The authors gratefully acknowledge financial support from the City University of Hong Kong. The work described in this paper was fully supported by a grant from the City University of Hong Kong (Project No. 7200060). 


\section{References}

Adithipyangkul, P. 2007. Non-monetary compensation and consumption externalities. Working paper, City University of Hong Kong.

Ai, J. 2006. Guanxi networks in China: Its importance and future trends. China \& World Economy, 14(5): 105-118.

Alon, I (Ed.). 2003. Chinese Culture, Organizational Behavior, and International Business Management. Westport, CT: Praeger.

Bai, C.E., \& Xu, L. C. 2005. Incentives for CEOs with multitasks: Evidence from Chinese state-owned enterprises. Journal of Comparative Economics, 33(3): 517-539.

Budhwar, P., \& Debrah, Y. A. 2009. Future research on human resources management systems in Asia. Asia Pacific Journal of Management, 26(2): 197-218.

Chen, C. C., \& Chen, X. 2009. Negative externalities of close guanxi within organizations. Asia Pacific Journal of Management, 26(1): 37-53.

Chiu, R. K., Luk, V. W., \& Tang, T. L. 2002. Retaining and motivating employees: Compensation preferences in Hong Kong and China. Personnel Review, 31(4): 402431.

Chow, I. H. 1992. Chinese workers' attitudes towards compensation practices in the People's Republic of China. Employee Relations, 14(3): 41-55.

Christensen, P. O., \& Feltham, G. A. 2005. Economics of Accounting, Volume II: Performance Evaluation. Boston: Kluwer Academic.

Conyon, M. J., \& He, L. 2008. Executive compensation and CEO equity incentives in China's listed firms. Working paper, ESSEC Business School, Wharton School, and SUNY.

Dale-Olsen, H. 2007. Fringe attraction, compensation policies, worker turnover and firm performance. Working paper, Institute for Social Research, Oslo. 
Eisenhardt, K. M. 1989. Agency theory: An assessment and review. Academy of Management Review, 14(1): 57-74.

Fama, E. F. 1980. Agency problems and the theory of the firm. Journal of Political Economy, 88(2): 288-307.

Firth, M., Fung, P. M. Y., \& Rui, O. M. 2006. Corporate performance and CEO compensation in China. Journal of Corporate Finance, 12(4): 693-714.

Firth, M., Fung, P. M. Y., \& Rui, O. M. 2007. How ownership and corporate governance influence chief executive pay in China's listed firms. Journal of Business Research, 60(7): 776-785.

Hayes, R. M., \& Schaefer, S. 2000. Implicit contracts and the explanatory power of top executive compensation for future performance. RAND Journal of Economics, 31(2): 273-293.

Jensen, M. C., \& Meckling, W. H. 1976. Theory of the firm: Managerial behavior, agency costs, and ownership structure. Journal of Financial Economics, 3(4): 305-360.

Kato, T., \& Long, C. X. 2005. Executive compensation, firm performance and corporate governance in China: Evidence from firms listed in the Shanghai and Shenzhen Stock Exchanges. Discussion paper no. 1767, Institute for the Study of Labor (IZA).

Li, D., Moshirian, F., Nguyen, P., \& Tan, L. W. 2007. Corporate governance or globalization: What determines CEO compensation in China? Research in International Business and Finance, 21: 32-49.

Long, J. E., \& Scott, F. A. 1982. The income tax and nonwage compensation. Review of Economics \& Statistics, 64(2): 211-219.

Luo, Y., \& Chen, M. 1997. Does guanxi influence firm performance? Asia Pacific Journal of Management, 14(1): 1-16. 
Marino, A. M., \& Zábojník, J. 2006. Work-related perks, agency problems, and optimal incentive contracts. Economics Department Working paper no. 1107, Queen's University.

McGregor, J. 2005. One Billion Customers: Lessons from the Front Lines of Doing Business in China. London: Nicholas Brealey.

Mengistae, T., \& Xu, L. C. 2004. Agency theory and executive compensation: The case of Chinese state-owned enterprises. Journal of Labor Economics, 22(3): 615-637.

Oyer, P. 2004. Salary or benefits? Working paper, Stanford University.

Park, S. H., \& Luo, Y. 2001. Guanxi and organizational dynamics: Organizational networking in Chinese firms. Strategic Management Journal, 22(5): 455-477.

Pfeffer, J., \& Sutton, S. I. 2006. Hard Facts, Dangerous Half-Truths and Total Nonsense: Profiting from Evidence-Based Management. Boston: Harvard Business Press.

Pierce, J. L., \& Newstrom, J. W. 1980. Toward a conceptual clarification of employee responses to flexible working hours: A work adjustment approach. Journal of Management, 6(2): 117-134.

Rajan, R. G., \& Wulf, J. 2006. Are perks purely managerial excess? Journal of Financial Economics, 79(1): 1-33.

Rosen, S. 2000. Overview: Does the composition of pay matter? In W. T. Alpert \& S. A. Woodbury (Eds.), Employee Benefits and Labor Markets in Canada and the United States: 13-30. Kalamazoo, MI: W.E. Upjohn Institute for Employment Research.

Yermack, D. 2006. Flights of fancy: Corporate jets, CEO perquisites, and inferior shareholder returns. Journal of Financial Economics, 80(1): 211-242.

Yeung, I. Y.M., \& Tung, R. L. 1996. Achieving business success in Confucian societies: The importance of guanxi (connections). Organizational Dynamics, 25(2): 54-65. 
Young, M. N., Peng, M. W., Ahlstrom, D., Bruton, G. D., \& Jiang, Y. 2008. Corporate governance in emerging economies: A review of the principal-principal perspective. Journal of Management Studies, 45(1): 196-220. 
Table 1 Sample Description

Panel A: By year

This panel presents the sample distribution by year.

\begin{tabular}{lcc}
\hline Year & Number & $\begin{array}{c}\text { As percentage of } \\
\text { sample }\end{array}$ \\
\hline 1999 & 199 & $5 \%$ \\
2000 & 161 & $4 \%$ \\
2001 & 646 & $17 \%$ \\
2002 & 843 & $23 \%$ \\
2003 & 884 & $24 \%$ \\
2004 & 973 & $26 \%$ \\
Total & 3,706 & $100 \%$ \\
\hline
\end{tabular}

Panel B: By industry

This panel provides the sample distribution by industry.

\begin{tabular}{lcc}
\hline Industry & Number & $\begin{array}{c}\text { As percentage } \\
\text { of sample }\end{array}$ \\
\hline Agriculture, Forestry, Animal Husbandry, and Fishing & 72 & $2 \%$ \\
Mining & 54 & $1 \%$ \\
Manufacturing & 2127 & $57 \%$ \\
Production and Distribution of Electricity, Gas, and Water & 195 & $5 \%$ \\
Construction & 62 & $2 \%$ \\
Transport, Storage, and Posts & 154 & $4 \%$ \\
Information Transmission, Computer Services, and & & \\
$\quad$ Software & 197 & $5 \%$ \\
Wholesale and Retail Trade & 252 & $7 \%$ \\
Real Estate & 172 & $5 \%$ \\
Management of Water Conservancy, Environment and & & \\
Public Facilities & 103 & $3 \%$ \\
Culture, Sports, and Entertainment & 14 & $0 \%$ \\
Conglomerates & 304 & $8 \%$ \\
Total & 3706 & $100 \%$ \\
\hline
\end{tabular}




\section{Table 2 Descriptive statistics}

\section{Panel A: Perks and compensation}

This table provides the descriptive statistics for the level of perk and cash compensation. PERKS1 is defined as the sum of expenditures for meals, travel, company cars, communications, socializing, and entertainment in the fiscal year. PERKS2 is defined as the expenditures for meals, travel, and entertainment in the fiscal year. COMPENSATION is the total cash compensation paid to the top three executive officers in the fiscal year. All the variables are measured in one million RMB.

\begin{tabular}{lcccc}
\hline VARIABLE & $\mathrm{N}$ & MEAN & MEDIAN & STD. DEV. \\
\hline PERKS1 & 3706 & 4.73 & 1.39 & 7.95 \\
PERKS2 & 3706 & 4.00 & 1.06 & 6.72 \\
COMPENSATION & 3706 & 0.42 & 0.30 & 0.37 \\
\hline
\end{tabular}

Panel B: Financial variables and stock return

This table provides the descriptive statistics for the financial data. ROA, return on assets, is defined as the net income divided by total assets at the end of the fiscal year. LEVERAGE is the ratio of total liability to total assets at the end of the fiscal year. MTB, the market-to-book equity ratio, is defined as the ratio of the market value to the book value of equity at the end of the fiscal year. LOG_SALES is the log of total sales in the fiscal year. STATE, the indicator for state-controlled firms, equals 1 if the company is controlled by the local or central government, and 0 if it is controlled by entrepreneurs.

\begin{tabular}{lcccc}
\hline & $\mathrm{N}$ & MEAN & MEDIAN & STD. DEV. \\
\hline ROA $(\%)$ & 3706 & 2.274 & 2.854 & 5.695 \\
LEVERAGE & 3706 & 0.467 & 0.469 & 0.180 \\
MTB & 3706 & 3.729 & 2.938 & 2.533 \\
LOG_SALES & 3706 & 20.264 & 20.233 & 1.175 \\
STATE & 3706 & 0.793 & 1.000 & 0.405 \\
\hline
\end{tabular}




\section{Table 3 Association of perks and compensation with firm performance}

This table provides the regression results for the association of perks and compensation with firm performance. The dependent variable is the log of PERKS1 plus one, PERKS2 plus one, and COMPENSATION plus one respectively in Models (1) to (3). The independent variables include: ROA, return on assets, measured as the net income divided by the total assets at the end of the fiscal year, STATE, an indicator variable, takes the value of 1 for state-controlled firms, and 0 otherwise, LEVERAGE, the ratio of total liability to total assets at the end of the fiscal year, MTB, market-to-book equity ratio, measured as the ratio of market value to book value of equity at the end of the fiscal year, and LOG_SALES, the logarithm value of total sales in the fiscal year. An OLS model with standard errors clustered by firm is applied. Yearly and industrial fixed effects are controlled but not reported. *,**, and *** stand for statistical significance at $10 \%, 5 \%$, and $1 \%$, respectively.

\begin{tabular}{lccc}
\hline & Model $(1)$ & Model $(2)$ & Model $(3)$ \\
& PERKS1 & PERKS2 & COMPENSATION \\
\hline ROA & 0.070 & 0.071 & 0.019 \\
& $(2.24)^{* *}$ & $(2.23)^{* *}$ & $(5.58)^{* * *}$ \\
STATE & -0.097 & -0.129 & -0.175 \\
& $(0.20)$ & $(0.26)$ & $(3.55)^{* * *}$ \\
LOG_SALES & 0.364 & 0.337 & 0.268 \\
LEVERAGE & $(1.79)^{*}$ & $(1.66)^{*}$ & $(11.88)^{* * *}$ \\
& -2.323 & -2.224 & -0.434 \\
MTB & $(1.79)^{*}$ & $(1.73)^{*}$ & $(3.23)^{* * *}$ \\
& 0.191 & 0.159 & 0.023 \\
Constant & $(2.08)^{* *}$ & $(1.72)^{*}$ & $(2.22)^{* *}$ \\
& 1.351 & 1.973 & 6.277 \\
Observations & $(0.33)$ & $(0.48)$ & $(14.33)^{* * *}$ \\
Adjusted R-squared & 3706 & 3706 & 3706 \\
\hline
\end{tabular}


Table 4 Association of perks and compensation with firm performance in sub-samples

Panel A: Firms with under- or over-paid cash compensation

This panel presents the regression results of the association of perks and compensation with firm performance among firms with higher performance and lower cash compensation and firms with lower performance and higher cash compensation. Firms with an average ROA above the median of the average ROA of each firm from 1999 to 2004 are regarded as firms with higher performance and firms with lower performance otherwise. Firms with an average cash compensation for the top three executives above the median of that for each firm from 1999 to 2004 are regarded as firms with higher pay, and firms with lower pay otherwise. The dependent variable is the log of PERKS1 plus one, PERKS2 plus one, and COMPENSATION plus one respectively in Models (1) to (3) and Models (4) to (6). The independent variables include: ROA, return on assets, measured as the net income divided by the total assets at the end of the fiscal year, STATE, an indicator variable, takes the value of 1 for state-controlled firms, and 0 otherwise, LEVERAGE, the ratio of total liability to total assets at the end of the fiscal year, MTB, market-to-book equity ratio, measured as the ratio of market value to book value of equity at the end of the fiscal year, and LOG_SALES, the logarithm value of total sales in the fiscal year. An OLS model with standard errors clustered by firm is applied. Yearly and industrial fixed effects are controlled but not reported. *,*, and *** stand for statistical significance at $10 \%, 5 \%$, and $1 \%$, respectively.

\begin{tabular}{|c|c|c|c|c|c|c|}
\hline & \multicolumn{3}{|c|}{ Firms with higher performance but lower cash pay } & \multicolumn{3}{|c|}{ Firms with lower performance but higher cash pay } \\
\hline & $\begin{array}{c}\text { Model (1) } \\
\text { PERKS1 }\end{array}$ & $\begin{array}{l}\text { Model (2) } \\
\text { PERKS2 }\end{array}$ & $\begin{array}{c}\text { Model (3) } \\
\text { COMPENSATION }\end{array}$ & $\begin{array}{c}\text { Model (4) } \\
\text { PERKS1 }\end{array}$ & $\begin{array}{l}\text { Model (5) } \\
\text { PERKS2 }\end{array}$ & $\begin{array}{c}\text { Model (6) } \\
\text { COMPENSATION }\end{array}$ \\
\hline ROA & $\begin{array}{c}0.354 \\
(2.45)^{* *}\end{array}$ & $\begin{array}{c}0.403 \\
(2.86)^{* * *}\end{array}$ & $\begin{array}{c}0.019 \\
(1.71)^{*}\end{array}$ & $\begin{array}{l}-0.080 \\
(1.32)\end{array}$ & $\begin{array}{l}-0.068 \\
(1.11)\end{array}$ & $\begin{array}{l}0.004 \\
(1.33)\end{array}$ \\
\hline STATE & $\begin{array}{l}0.365 \\
(0.28)\end{array}$ & $\begin{array}{l}0.495 \\
(0.38)\end{array}$ & $\begin{array}{l}0.006 \\
(0.07)\end{array}$ & $\begin{array}{l}-1.616 \\
(1.49)\end{array}$ & $\begin{array}{l}-1.641 \\
(1.51)\end{array}$ & $\begin{array}{c}-0.164 \\
(2.66)^{* * *}\end{array}$ \\
\hline LOG_SALES & $\begin{array}{l}-0.159 \\
(0.30)\end{array}$ & $\begin{array}{l}-0.225 \\
(0.43)\end{array}$ & $\begin{array}{l}0.062 \\
(1.54)\end{array}$ & $\begin{array}{l}0.190 \\
(0.42)\end{array}$ & $\begin{array}{l}0.129 \\
(0.28)\end{array}$ & $\begin{array}{c}0.142 \\
(6.21)^{* * *}\end{array}$ \\
\hline LEVERAGE & $\begin{array}{l}1.342 \\
(0.41)\end{array}$ & $\begin{array}{l}2.505 \\
(0.78)\end{array}$ & $\begin{array}{l}-0.046 \\
(0.17)\end{array}$ & $\begin{array}{r}-1.350 \\
(0.41)\end{array}$ & $\begin{array}{l}-0.285 \\
(0.09)\end{array}$ & $\begin{array}{l}-0.121 \\
(0.69)\end{array}$ \\
\hline MTB & $\begin{array}{l}-0.464 \\
(1.66)^{*}\end{array}$ & $\begin{array}{c}-0.609 \\
(2.35)^{* *}\end{array}$ & $\begin{array}{l}0.009 \\
(0.54)\end{array}$ & $\begin{array}{l}0.047 \\
(0.23)\end{array}$ & $\begin{array}{r}-0.000 \\
(0.00)\end{array}$ & $\begin{array}{l}0.008 \\
(0.69)\end{array}$ \\
\hline Constant & $\begin{array}{c}13.148 \\
(1.30)\end{array}$ & $\begin{array}{l}14.044 \\
(1.42)\end{array}$ & $\begin{array}{c}9.684 \\
(13.30)^{* * *}\end{array}$ & $\begin{array}{l}3.714 \\
(0.40)\end{array}$ & $\begin{array}{l}4.893 \\
(0.53)\end{array}$ & $\begin{array}{c}9.276 \\
(21.04)^{* * *}\end{array}$ \\
\hline Observations & 755 & 755 & 755 & 756 & 756 & 756 \\
\hline Adjusted R-squared & 0.06 & 0.07 & 0.35 & 0.05 & 0.05 & 0.37 \\
\hline
\end{tabular}


Table 4 Association of perks and compensation with firm performance in sub-samples

Panel B: Firms with cash compensation aligned with performance

This panel presents the regression results of the association of perks and compensation with firm performance in firms with lower performance and lower cash pay and firms with higher performance and higher cash pay. Firms with an average ROA above the median of the average ROA for each firm from 1999 to 2004 are regarded as firms with higher performance, and firms with lower performance otherwise. Firms with an average cash compensation for the top three executives above the median of that for each firm from 1999 to 2004 are regarded as firms with higher cash pay, and firms with lower cash pay otherwise. The dependent variable is the log of PERKS1 plus one, PERKS2 plus one, and COMPENSATION plus one respectively in Models (1) to (3) and Models (4) to (6). The independent variables include: ROA, return on assets, measured as the net income divided by the total assets at the end of the fiscal year, STATE, an indicator variable, takes the value of 1 for statecontrolled firms, and 0 otherwise, LEVERAGE, the ratio of total liability to total assets at the end of the fiscal year, MTB, market-to-book equity ratio, measured as the ratio of the market value to the book value of equity at the end of the fiscal year, and LOG_SALES, the logarithm value of total sales in the fiscal year. An OLS model with standard errors clustered by firm is applied. The yearly and industrial fixed effects are controlled but not reported. *, **, and *** stand for statistical significance at 10\%, 5\%, and 1\%, respectively.

\begin{tabular}{|c|c|c|c|c|c|c|}
\hline & \multicolumn{3}{|c|}{ Firms with lower performance and lower cash pay } & \multicolumn{3}{|c|}{ Firms with higher performance and higher cash pay } \\
\hline & $\begin{array}{l}\text { Model (1) } \\
\text { PERKS1 }\end{array}$ & $\begin{array}{l}\text { Model (2) } \\
\text { PERKS2 }\end{array}$ & $\begin{array}{c}\text { Model (3) } \\
\text { COMPENSATION }\end{array}$ & $\begin{array}{l}\text { Model (4) } \\
\text { PERKS1 }\end{array}$ & $\begin{array}{l}\text { Model (5) } \\
\text { PERKS2 }\end{array}$ & $\begin{array}{c}\text { Model (6) } \\
\text { COMPENSATION }\end{array}$ \\
\hline ROA & $\begin{array}{l}0.043 \\
(1.03)\end{array}$ & $\begin{array}{l}0.039 \\
(0.94)\end{array}$ & $\begin{array}{c}0.009 \\
(2.43)^{* *}\end{array}$ & $\begin{array}{l}0.153 \\
(1.21)\end{array}$ & $\begin{array}{l}0.148 \\
(1.15)\end{array}$ & $\begin{array}{c}0.041 \\
(4.44)^{* * *}\end{array}$ \\
\hline STATE & $\begin{array}{l}0.452 \\
(0.56)\end{array}$ & $\begin{array}{l}0.310 \\
(0.39)\end{array}$ & $\begin{array}{c}-0.154 \\
(2.32)^{* *}\end{array}$ & $\begin{array}{l}0.505 \\
(0.57)\end{array}$ & $\begin{array}{l}0.499 \\
(0.57)\end{array}$ & $\begin{array}{c}-0.153 \\
(2.69) * * *\end{array}$ \\
\hline LOG_SALES & $\begin{array}{c}0.942 \\
(2.72)^{* * *}\end{array}$ & $\begin{array}{c}1.047 \\
(3.05)^{* * *}\end{array}$ & $\begin{array}{c}0.093 \\
(2.71)^{* * *}\end{array}$ & $\begin{array}{l}-0.173 \\
(0.41)\end{array}$ & $\begin{array}{l}-0.248 \\
(0.60)\end{array}$ & $\begin{array}{c}0.124 \\
(4.94)^{* * *}\end{array}$ \\
\hline LEVERAGE & $\begin{array}{l}-3.030 \\
(1.49)\end{array}$ & $\begin{array}{l}-3.320 \\
(1.65)\end{array}$ & $\begin{array}{l}-0.203 \\
(1.16)\end{array}$ & $\begin{array}{l}0.061 \\
(0.02)\end{array}$ & $\begin{array}{l}-1.192 \\
(0.39)\end{array}$ & $\begin{array}{l}0.125 \\
(0.74)\end{array}$ \\
\hline MTB & $\begin{array}{c}0.287 \\
(2.05)^{* *}\end{array}$ & $\begin{array}{c}0.284 \\
(2.05)^{* *}\end{array}$ & $\begin{array}{l}0.006 \\
(0.59)\end{array}$ & $\begin{array}{c}0.541 \\
(2.36)^{* *}\end{array}$ & $\begin{array}{c}0.543 \\
(2.38)^{* *}\end{array}$ & $\begin{array}{l}-0.021 \\
(1.55)\end{array}$ \\
\hline Constant & $\begin{array}{l}-8.964 \\
(1.28)\end{array}$ & $\begin{array}{c}-10.806 \\
(1.57)\end{array}$ & $\begin{array}{c}9.661 \\
(15.00)^{* * *}\end{array}$ & $\begin{array}{l}8.344 \\
(0.99)\end{array}$ & $\begin{array}{l}9.930 \\
(1.20)\end{array}$ & $\begin{array}{c}9.281 \\
(19.08)^{* * *}\end{array}$ \\
\hline Observations & 1097 & 1097 & 1097 & 1098 & 1098 & 1098 \\
\hline Adjusted R-squared & 0.06 & 0.06 & 0.37 & 0.05 & 0.07 & 0.41 \\
\hline
\end{tabular}


Table 5 Relationships between perks and cash compensation and future performance

This table shows the relationships between perks and cash compensation and future firm performance. The dependent variable is ROA in one, two, and three years ahead respectively in Models (1) and (2), Models (3) and (4), and Models (5) and (6). The independent variables include the

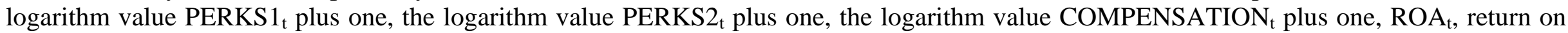
assets, measured as the net income divided by the total assets at the end of year $\mathrm{t}, \mathrm{STATE}_{\mathrm{t}}$, an indicator variable, takes the value of 1 for state-

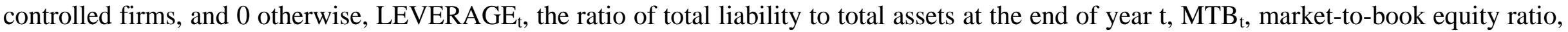
measured as the ratio of market value to book value of equity at the end of year $t$, and LOG_SALES ${ }_{t}$, the logarithm value of total sales in year $t$. An OLS model with standard errors clustered by firm is applied. Yearly and industrial fixed effects are controlled but not reported. *, **, and *** stand for statistical significance at $10 \%, 5 \%$, and $1 \%$, respectively.

\begin{tabular}{|c|c|c|c|c|c|c|}
\hline & \multicolumn{2}{|c|}{$\mathrm{ROA}_{t+1}$} & \multicolumn{2}{|c|}{$\mathrm{ROA}_{\mathrm{t}+2}$} & \multicolumn{2}{|c|}{$\mathrm{ROA}_{\mathrm{t}+3}$} \\
\hline & Model (1) & Model (2) & Model (3) & Model (4) & Model (5) & Model (6) \\
\hline COMPENSATION $_{t}$ & $\begin{array}{c}0.388 \\
(3.28) * * *\end{array}$ & $\begin{array}{c}0.391 \\
(3.30)^{* * *}\end{array}$ & $\begin{array}{c}0.522 \\
(3.70)^{* * *}\end{array}$ & $\begin{array}{c}0.524 \\
(3.71)^{* * *}\end{array}$ & $\begin{array}{c}0.375 \\
(2.08)^{* *}\end{array}$ & $\begin{array}{c}0.375 \\
(2.08)^{* *}\end{array}$ \\
\hline PERKS $1_{t}$ & $\begin{array}{c}0.030 \\
(2.78)^{* * *}\end{array}$ & & $\begin{array}{c}0.034 \\
(2.49)^{* *}\end{array}$ & & $\begin{array}{l}0.032 \\
(1.84)^{*}\end{array}$ & \\
\hline PERKS $2_{t}$ & & $\begin{array}{c}0.035 \\
(3.07)^{* * *}\end{array}$ & & $\begin{array}{c}0.034 \\
(2.52)^{* *}\end{array}$ & & $\begin{array}{c}0.029 \\
(1.68)^{*}\end{array}$ \\
\hline $\mathrm{ROA}_{t}$ & $\begin{array}{c}0.421 \\
(15.88)^{* * *}\end{array}$ & $\begin{array}{c}0.421 \\
(15.89)^{* * *}\end{array}$ & $\begin{array}{c}0.253 \\
(9.33)^{* * *}\end{array}$ & $\begin{array}{c}0.253 \\
(9.33)^{* * *}\end{array}$ & $\begin{array}{c}0.211 \\
(5.45)^{* * *}\end{array}$ & $\begin{array}{c}0.211 \\
(5.46) * * *\end{array}$ \\
\hline LOG_SALES $_{\mathrm{t}}$ & $\begin{array}{c}0.866 \\
(7.91)^{* * *}\end{array}$ & $\begin{array}{c}0.864 \\
(7.88)^{* * *}\end{array}$ & $\begin{array}{c}0.845 \\
(6.85)^{* * *}\end{array}$ & $\begin{array}{c}0.845 \\
(6.85) * * *\end{array}$ & $\begin{array}{c}0.891 \\
(5.89)^{* * *}\end{array}$ & $\begin{array}{c}0.893 \\
(5.90) * * *\end{array}$ \\
\hline LEVERAGE $_{\mathrm{t}}$ & $\begin{array}{c}-4.380 \\
(6.87) * * *\end{array}$ & $\begin{array}{c}-4.371 \\
(6.85)^{* * *}\end{array}$ & $\begin{array}{c}-4.862 \\
(6.42)^{* * *}\end{array}$ & $\begin{array}{c}-4.864 \\
(6.42)^{* * *}\end{array}$ & $\begin{array}{c}-3.970 \\
(3.93) * * *\end{array}$ & $\begin{array}{c}-3.980 \\
(3.93) * * *\end{array}$ \\
\hline $\mathrm{MTB}_{\mathrm{t}}$ & $\begin{array}{c}0.366 \\
(6.20)^{* * *}\end{array}$ & $\begin{array}{c}0.366 \\
(6.21)^{* * *}\end{array}$ & $\begin{array}{c}0.286 \\
(4.28)^{* * *}\end{array}$ & $\begin{array}{c}0.287 \\
(4.30)^{* * *}\end{array}$ & $\begin{array}{c}0.158 \\
(2.07)^{* *}\end{array}$ & $\begin{array}{c}0.160 \\
(2.08)^{* *}\end{array}$ \\
\hline Constant & $\begin{array}{c}-21.517 \\
(9.63)^{* * *}\end{array}$ & $\begin{array}{c}-21.564 \\
(9.67)^{* * *}\end{array}$ & $\begin{array}{c}-24.218 \\
(9.01)^{* * *}\end{array}$ & $\begin{array}{c}-24.257 \\
(9.02)^{* * *}\end{array}$ & $\begin{array}{c}-23.805 \\
(7.05)^{* * *}\end{array}$ & $\begin{array}{c}-23.826 \\
(7.05) * * *\end{array}$ \\
\hline Observations & 3925 & 3925 & 3855 & 3855 & 2806 & 2806 \\
\hline Adjusted R-squared & 0.28 & 0.28 & 0.17 & 0.17 & 0.13 & 0.13 \\
\hline
\end{tabular}


Figure 1 Firm Stratification

\begin{tabular}{|c|c|c|}
\hline & High Performance & Low Performance \\
\hline $\begin{array}{c}\text { Low Cash } \\
\text { Compensation }\end{array}$ & Group 1 & Group 3 \\
\hline $\begin{array}{c}\text { High Cash } \\
\text { Compensation }\end{array}$ & Group 4 & Group 2 \\
\hline
\end{tabular}

